\title{
The Politics of Civic Combinations
}

\author{
Laszlo Bruszt $\cdot$ Balazs Vedres
}

(C) International Society for Third-Sector Research and The Johns Hopkins University 2008

\begin{abstract}
In this article, we explore the ways in which partnerships with the state within state-led developmental programs might effect the autonomy of civic organizations (COs) and their readiness to enter in political action. To identify the relationship between collaboration with the state and civic autonomy we draw on data from a survey of 740 Hungarian regional civic associations. We did not find support for the theses that mixing with the state might undermine the autonomy of COs and lead to their political neutralization. Also, we did not find support for the hypotheses that political action is solely about money or it is the property of non-autonomous NGOs. We have identified several mechanisms that allow COs to combine participation in partnership projects with maintained autonomy and political activism.
\end{abstract}

Résumé Dans cet article nous explorons les façons dans lesquelles les partenariats avec l'état dans le cadre des programmes d'organisations civiques peuvent affecter l'autonomie des organisations civique s (COs : Civic Organizations) et leur empressement d'entrer dans l'action politique Pour identifier la relation entre la collaboration de l'état et de l'autonomie civique nous tirons les données d'une enquête portant sur sept-cent quarante (740) associations civiques régionales hongroises. Nous n'avons pas constaté de soutien pour celles-ci ; le mélange en avec l'état pourrait saper l'autonomie des COs et mener à leur neutralisation politique. Aussi, nous n'avons pas trouvé d'assistance pour les hypothèses stipulant que l'action politique concerne uniquement l'octroi de finances ou est la propriété des

\footnotetext{
L. Bruszt $(\bowtie)$

Department of Social and Political Science, European University Institute, San Domencio di Fiesole, Firenze, Italy

e-mail: laszlo.bruszt@eui.eu

B. Vedres

Department of Sociology and Social Anthropology, Central European University,

Budapest, Hungary

e-mail: Vedresb@ceu.hu
} 
MGOs d'actions autonomes. Nous avons identifié plusieurs mécanismes qui permettent aux COs de combiner la participation dans des projets avec l'autonomie maintenue et l'activisme politique.

Zusammenfassung Dieser Beitrag untersucht, inwieweit Partnerschaften mit dem Staat innerhalb staatlich geführter Entwicklungsprogramme die Autonomie bürgerlicher Organisationen und ihre Bereitschaft zur aktiven Teilnahme am Politikgeschehen beeinflussen können. Zur Verdeutlichung der Beziehung zwischen der Zusammenarbeit mit dem Staat und der bürgerlichen Autonomie beruft sich der Beitrag auf Daten aus einer Befragung von 740 ungarischen regionalen Bürgervereinigungen. Thesen, die besagen, dass die Verbindung zum Staat die Autonomie bürgerlicher Organisationen untergraben und zu ihrer politischen Neutralisierung führen könnte, konnten nicht belegt werden. Des Weiteren wurden keine Beweise für die Hypothesen gefunden, dass es bei einer aktiven politischen Teilnahme ausschließlich um Geld geht oder diese nicht-autonomen nicht-staatlichen Organisationen vorbehalten bleibt. Es ?tul?> wurden mehrere Mechanismen herausgestellt, die es Bürgerorganisationen erlauben, an Partnerschaftsprojekten teilzunehmen und gleichzeitig ihre Autnomie zu wahren und eine aktive Teilnahme am Politikgeschehen fortzuführen.

Resumen En este trabajo se analiza la influencia que las alianzas con el estado en programas de desarrollo dirigidos por éste podrían tener en la autonomía de las organizaciones cívicas y su disponibilidad a participar en medidas políticas. Para identificar la relación entre la colaboración con el estado y la autonomía cívica, hemos utilizado los datos de un sondeo realizado a 740 asociaciones cívicas regionales húngaras. En él, no hallamos ninguna conclusión que respaldara la tesis según la cual negociar con el estado podría perjudicar la autonomía de las organizaciones cívicas y provocar su neutralización política. Tampoco encontramos nada que respaldara las hipótesis de que el único objeto de la acción política es conseguir dinero o que es propiedad exclusiva de las ONG no autónomas. También hemos identificado varios mecanismos que permitirían a las organizaciones cívicas participar en los proyectos de asociación conservando su autonomía y haciendo al mismo tiempo activismo político.

Keywords Civic organizations - Developmental partnerships $\cdot$ Partnership projects · Civic autonomy $\cdot$ Civil society $\cdot$ Political action · Hungary

\section{Research Questions}

Over the last decade social and developmental partnerships increasingly involved civic organizations. The emergence of these new localized developmental partnership forms originates from a previous episode of institutional experimentation. ${ }^{1}$ Faced with the failures of various market- and state-led developmental

\footnotetext{
1 For critical overview of the literature on developmental partnerships, see Howell and Pearce (2002) and Kaldor et al. (2003).
} 
programs, national governments, international financial institutions, and multilateral development agencies search for a third way, or a new way to organize development (Evans 1997; Howell and Pearce 2002). With the goals of inducing economic growth, furthering the development of market institutions, or increasing social and economic cohesion, international developmental agencies have played a major role in reviving the search for ways to capitalize on the collective problem-solving capacities of combined local stakeholders (OECD 1995; UNDP 1993, 1995; World Bank 1992, 1996). Such partnership projects, with state, business, and civic participation became one of the most contested forms of institutional experimentation. While some describe these institutional developments as democratic innovation, others see them as new forms of depoliticization and domination.

Developmental partnerships that combine civic organizations with state and market actors are viewed in two diametrically opposing ways in the literature. For those who are supportive, the combination of civic organizations with diverse state and non-state actors represents an innovative form of institutional experimentation. In their view it allows diverse actors in local societies to combine and address problems of market and state failure. ${ }^{2}$ These combinations represent an alternative way of governing collective action among actors from diverse organizational fields with a stake in local social and economic development. The inclusion of civic organizations (COs) in such developmental programs and policy-making is seen from this perspective as empowering, giving room for COs to represent interests, considerations, and values that would otherwise be excluded. From this perspective civic combination with state and market actors is seen as a mechanism that allows for decentralized social experimentation and for accommodating a greater diversity of social goals in developmental programs (Brown et al. 2001; Bruszt and Stark 2003; Gerstenberg and Sabel 2002; Sabel 1993, 1994, 1996; Stark et al., Unpublished manuscript, 2005).

Many others strongly reject these developmental combinations, arguing that they are nothing but merely a cost-effective way of alleviating some of the social and economic side effects of, variously, neoliberal policies, the downsizing of the welfare state, or top-down developmental programs. ${ }^{3}$ The combination of COs with diverse state and market actors at the domestic and supra-national levels turns them into service organizations, "corporatizing" and depoliticizing them, leading to a

\footnotetext{
2 There are several roots of this approach. In economic sociology and the literature on forms of economic governance, the works of Charles Sabel, Wolfgang Streeck, and Philippe C. Schmitter influenced most the thinking about the role played by developmental associations or associative action (Sabel 1993, 1994, 1996; Streeck and Schmitter 1985). On linking local associative action and democratic experimentalism in the framework of the concept of "directly deliberative polyarchy" see Sabel and Cohen (1997). Another direction that influenced thinking on different developmental partnerships came from the literature on the nonprofit sector linking associative action to the production of diverse types of public goods (see the work of Powell and Clemens 1998). On deliberative association in post-socialist transformation see Stark and Bruszt (1998).

3 For example, Kaldor, Anheier, and Glasius in their introductory chapter to Global Civil Society 2003 subsume these combinations at the supra-national level under the rubric of new public management and talk about the "basically neo-liberal role NGOs assume in public management manifestations." (p. 9) See also Chandhoke (2002), Kettle (2000), and Perrow (2001, 2002). For a more balanced critique of NGO participation in partnerships see Howell and Pearce (2002).
} 
loss of autonomy. In this approach, partnerships with state and business are contrasted with the civic associationism of a "strong and vibrant civil society," and with civic political activism, the "source of dissent, challenge and innovation, a countervailing force to government and the corporate sector" (Kaldor et al. 2003, pp. 1-17). If the political participation of COs in policy making is mentioned, it is described as a means to "provide a semblance of democratic legitimacy" (Anderson 2000). Instead of empowerment, this area within the literature presents their participation in partnerships with state and/or business as a mechanism of disempowerment, and depoliticization.

Our task in this article is to study the relationship between closeness to the state and civic autonomy. To do so, we have conducted a survey of 740 of the largest civic associations in three Hungarian regions, allowing us (1) to document the prevalence of their interactions with the state and other non-civic actors charting the varieties these interactions take, and (2) to document the prevalence of various developmental goals and diverse types of political action undertaken by these organizations, and to register changes in their goals and political activities. Most importantly, our data allow us (3) to analyze the relationship between these processes as we investigate whether interactions with the state come at the expense of the autonomy of civic organizations, their depoliticizing, or their giving up on (some of) their goals. Are Hungarian civic associations losing their autonomy just at the moment when they reach out to participate in collaborative developmental projects? Or are there mechanisms at work that allow collaborative associations with state and other actors outside the civic sector to co-exist with the maintenance of civic autonomy?

These questions are especially important from the viewpoint of the evolution of fledgling civil societies in the Central European new member countries of the European Union. The introduction of new European developmental programs in these countries led to a rapid increase in the numbers of diverse local and regional developmental partnership projects. In Hungary, for example, more than 20,000 projects were submitted for consideration during the first year of the National Development Plan, with around half involving civic organizations. In our survey of the largest regional $\mathrm{CO}$ projects in Hungary we found that nearly two-third of $\mathrm{CO}$ projects involved collaboration with actors from diverse organizational fields (state, business, science, education, media, church, etc.). In more than half of the projects, the partners of COs included at least one (local, regional, or national) state actor. ${ }^{4}$

Civic organizations in these countries are drawn into partnership projects within a political framework that provides central state agencies with the right to define developmental goals and "best practice" in achieving them (Bruszt 2002). Put differently, the increasing inclusion of civic organizations in diverse partnership projects in these countries goes hand in hand with attempts at (re)centralization and the technocratic de-politicization of regional development. COs are invited primarily to compete ("tender") for the right to participate in the implementation of the centrally defined developmental programs. They have only a weak formal right to be consulted by planning authorities and must engage in political action if

\footnotetext{
$\overline{4}$ Information based on interview in the Ministry of Economy and Trade (June 2005, Budapest).
} 
they wish to influence the formation of these developmental programs. But do they? Or do these societies face a forced choice between civic autonomy and mixing with the state?

We test several of these assumptions about the relationship between closeness to the state and autonomy of the COs below. We proceed in three steps, starting with the assumption that proximity to the state goes together with a loss of autonomy in civil society. First we analyze how the presence of a state partner in $\mathrm{CO}$ projects or ongoing activities affects changes in the number or mixture of goals, the loss of certain goals, and changes in political activism. Here, our assumption was that, if mixing with the state would result in a loss of civic autonomy, we would find a narrower (less diverse) mix of goals, loss of a goal, and decreased political activism by COs that enter into partnerships with the state. As we will see below, these expectations have proven to be unsupported by the data. We do find COs that give up on certain of their goals, and that leave political action, but we cannot explain these changes by their closeness to the state. Rather, goal loss or political deactivation goes hand in hand with a distancing from the state.

In the second step, we test three alternative explanations for the loss of CO autonomy. None of these tests yields affirmative results. Collaborating with business works similarly to partnership with the state: it seems to hurt neither civic values nor goals. Nor do stopping collaboration with other civic organizations or getting out of public attention by cutting collaborative ties to media organizations account for loss in autonomy per se. It seems that civic control is maintained through different channels, not primarily through direct partnering with other NGOs or the media.

Here we are interested in the relationship between closeness to the state and the autonomy of COs. We were unable to find a positive answer to the question about the sources of declining $\mathrm{CO}$ autonomy. Given our measures for $\mathrm{CO}$ autonomy, we could "only" establish that the idea of closeness to the state going together with diminishing autonomy can be rejected. We find that a decline in the number and diminishing mix of goals, and waning political activism go together with distancing from the state. But do our indicators really measure autonomy? Is it not for example possible that, just to the contrary, presence or increase in political activism might indicate the loss or lack of autonomy? In the third step, we relax the assumption that political activism-our most important indicator-stands for civic autonomy, and instead test two hypotheses concerning political activism as sign for lost or absent autonomy. One first reason for political engagement might be that COs "go for the money:" thus, political activism could be predicted by prior funding from the state. A second reason may be that it is not the autonomous COs but rather the NGOs created by the (local) state which engage in political action. Around one-third of regional NGOs in Hungary were created not by civic actors but by the local state, and we might find that the state-created organizations are primarily behind political activism. We test both of these hypotheses: if loss of autonomy or the absence thereof has independent explanatory power in accounting for political action, we cannot reject the assumption, held by representatives of the pessimistic view, that closeness to the state and organizational autonomy are negatively related. 
We have no reasons to assume that it is only the loss of autonomy or its absence which can stand for political activism. In our model accounting for political activism we controlled several alternative explanations for political activism drawing freely on organizational theories and theories developed on the basis of the study of the political organization of business interests. We found no support for the thesis that political activity is solely about money, or that activism would be the preserve of state-made NGOs. We identify several mechanisms that make COs combine participation in partnership projects with autonomous political action.

\section{Research Data}

To identify the relationship between collaboration with the state and civic autonomy we draw on data from a survey of Hungarian regional civic associations that we conducted in 2003 in three "statistical regions." 5 From among the seven "statistical regions," we choose the following three: Western Hungary, the most developed region in Hungary that received the largest share of the foreign direct investment from among different regions; the Northern Plain, the region most affected by the social and economic dislocations of economic transformation in Hungary; and the Southern Plain, a region representing roughly the Hungarian average, both in the level of economic development and in the types of problems that it faces. Using the database of the Hungarian Statistical Office (HSO) on NGOs in these three regions we compiled a list that ranked nonprofit organizations by the size of their budgets. We excluded organizations in the field of sports (e.g., soccer leagues) and leisure time activities (e.g., stamp collectors) as well as foundations whose sole purpose is to support a single organization (e.g., the fund-raising arm of a museum, hospital, school, or church). From the remaining list, one-third of the organizations are "subsidiaries" of the local state: an NGO created by the local government. These organizations were not excluded from the list; instead, their presence in the sample allows us to compare the autonomy and political activity of COs and "subsidiary" NGOs. We employed students of the Institute of Social and European Studies (ISES) at Daniel Berzsenyi College in Szombathely, which has a center of regional studies with a strong track record in empirical research on regional development, to administer our survey instrument of face-to-face interviews, typically with the elected president or chief executive officer of the organization, or their deputies. From an initial list of approximately 900 of the largest civic associations in these three "regions" we were able to successfully contact 740 organizations distributed roughly equally among the three "regions."

We took as a unit of our analysis the projects of these organizations. We asked the representatives of these organizations to tell us how many projects they had undertaken during the last two years. If they had more than three projects we asked

\footnotetext{
5 "Statistical regions" were created in Hungary during the process of preparation for the reception of EU regional development funds. As the name suggests, these "regions" do not have autonomous political representation.
} 
them to identify the three most important ones and then asked questions concerning these projects. If they had three or less we asked questions concerning these projects. If they had none, we asked questions about their ongoing activity.

We defined closeness to the state as active collaboration with at least one type of state agency in developmental projects and/or in the ongoing activities of a $\mathrm{CO}$. We measure state proximity by the presence of a state partner in projects or ongoing activity. Civil society autonomy, with reference to civic organizations was defined as the power to make the rules that govern the internal affairs of the organization. The most important of these internal affairs is setting the goals of the organization. A $\mathrm{CO}$ is autonomous to the degree to which it can uphold its own values while selectively taking into account the interests of others, making use of diverse external opportunities. We measure civil society autonomy along the following dimensions: change of goal mix (the number of goals), loss of a certain goal, and changes in political activism.

We defined a project as "combinatory" if it had two or more different types of goals and had two or more types of collaborative partners. For the identification of goals pursued in the projects we have used a list of 22 developmental goals that we took from the Regional Development Plans of these three regions. ${ }^{6}$ For each project we asked whether the furthering of any of these goals was among the goals pursued by the project. To identify the partners involved in these projects we used a list of 15 types of actors and for each project asked which had participated in the project. ${ }^{7}$

Political activism in general refers to intentional action to bring about social or political change. Activism might be oriented towards diverse social constituencies or towards various authorities, or might combine both. In the first case, COs might try to create change by trying to alter the way people see specific issues, or to make them act and thereby attain their active participation in collective action. In the second case, we are concerned with action by COs to alter regulations, laws and/or policies directly or indirectly at various levels of the state. Direct forms of political action include attempts to alter regulations or laws at different levels of the state, or lobbying for a policy goal. We define indirect forms of political action as attempts to change balance of forces in the CO's area of the activity.

For the first dimension of political activism, viz. that oriented towards diverse social constituencies we asked questions about how often the organization tries to change public opinion, to induce their active participation and/or to increase bottom

\footnotetext{
6 The list consisted of various social goals (improving health conditions, improving social conditions, improving education, increasing employment, strengthening higher education) economic goals (furthering industrial development, furthering agricultural development, development of tourism, development of firm creation, strengthening economic innovation, furthering capital influx in the region) environmental goals (improving the quality of environment, optimal use of environmental resources, environmental education) and general regional goals (improve transportation within the region, improve internal cohesion in the region, improve external territorial relations of the region, further cross-territorial communication, improving the administrative, political institutions of the region).

7 The list of actors used in the questionnaire: donors, central government, county government, local government, Regional Development Council/Regional Development Agency, political party, other domestic NGO, foreign NGO, international organization, church, media, a business organization, scientific organization, and trade union.
} 
up initiatives in general. For political activism oriented towards authorities, we asked how often the organization tries to put issues on the political agenda, to change regulations at the level of national or local/regional government and/or alter the balance of forces in its own area of activity ("never," "sometimes," "often," "always"). To identify project-related political activity we asked of each project separately whether it included any of the following activities: organization of a demonstration; petitioning; lobbying the parliament; lobbying the central government; lobbying country and lobbying local government. We found a strong correlation between activism oriented towards social constituencies and activism oriented towards authorities: those engaged in one of these types of activism are significantly more likely to engage in one of the activities that form part of the other dimension. Because in this article we discuss the effects of closeness to the state we focus on forms of political activism oriented towards the authorities.

As an alternative explanation for political activity we used embedding in local society. We defined embedding as relationships of formal and informal accountability which tie a $\mathrm{CO}$ to diverse actors in local society. We speak of formal accountability when a local $\mathrm{CO}$ has to report formally to various local social actors. We speak of informal accountability when a local $\mathrm{CO}$ has to take into account the interests of various local actors when making decisions. We have included members, clients, other domestic NGOs, media and newspapers, trade unions, and the general public amongst local social actors. Because of their increased local activity in Hungary, we have also added foreign NGOs to this list. For each of these types of actors, we asked how often the $\mathrm{CO}$ has to report to them and how often it has to take their interests into account when making decisions ("never," "sometimes," "often," or "always").

\section{State Proximity and Autonomy}

The assumption in the literature on civil society is that proximity to the state goes together with a loss of autonomy in civil society. To evaluate this hypothesis we need to operationalize two concepts: state proximity and civil society autonomy. We measure state proximity by the presence of a state partner in $\mathrm{CO}$ projects or ongoing activity. We measure civil society autonomy along the following dimensions: change of goal mix (the number of types of goals, e.g., economic, social, environmental), loss of a goal, and change in political activism. To address the dynamics of civil society autonomy, we only use those COs that had at least one project so that we can compare with ongoing activities, assuming that ongoing activities precede that project. Since only about half of the organizations engaged in projects, we work with between 347 and 383 cases, depending on missing responses to the variable in focus.

After operationalizing state proximity and civil society autonomy, the next and simplest step is to create a two-by-two table: proximity to the state or no proximity, by autonomy or no autonomy (Table 1). (Logistic regressions then provide more sophisticated versions of this simple table including controls.) 
Table 1 State proximity and goal mix

\begin{tabular}{llllll}
\hline & & \multicolumn{2}{l}{ Single goal } & Total \\
\cline { 4 - 5 } & & & No & Yes & \\
\hline State proximity & No & Count & 76 & 84 & 160 \\
& & Row $\%$ & 47.5 & 52.5 & 100.0 \\
& Yes & Adj. Res. & -2.5 & 2.5 & 187 \\
& & Count & 114 & 73 & 100.0 \\
Total & Row $\%$ & 61.0 & 39.0 & 347 \\
& & Adj. Res. & 2.5 & -2.5 & 100.0 \\
\hline$\chi^{2}=6.31, p=.012$ & & Count & 190 & 157 & 45.2 \\
\end{tabular}

\section{State Proximity and Goals}

In this first test we focus on the goals of the organization. Goals represent a fundamental level of organizational autonomy. Resources, regulations, activism are aspects that are influenced by many contingencies, scarcities, or limitations in organizational capacities. Setting goals is somehow prior to these operational steps. We argue that if we find that state proximity leads to the loss of goals, then we capture a fundamental process of losing autonomy.

Table 1 shows that with this first approach we can reject the hypothesis that state proximity goes together with a narrower definition of goals. Those NGOs that are proximate to the state are more likely to have multiple goals (a more diversified goal mix).

Why go further? With this table we do not know if those NGOs that become proximate to the state were different from the state-less NGOs in terms of their goals before they became proximate to the state. There are several mechanisms that one can cite, and which would predict that goal diversification can lead to state proximity. For example: more diverse goals mean that there is a higher likelihood of meeting more diverse partners, and so a higher likelihood of meeting state actors. It may then be that this state partnership makes some of these diversified organizations drop their goals.

This simple model leaves many questions open. The first and most important is: does state proximity cause loss of autonomy, or does lack of autonomy cause state proximity? Moreover, state proximity and lack of autonomy can arise at the same moment, in the case of state created NGOs. This prompts a dynamic analysis: beyond measuring state proximity we should measure tendencies in state proximity (moving towards the state, or away from the state, or staying close, or staying away). We also need to measure tendencies in autonomy in the same way. This allows a temporal order to be established.

The basic table in this approach is a four-by-four table (Table 2). This table provides further evidence to reject the hypothesis that state proximity leads to the loss of civil society autonomy. According to the hypothesis, an NGO moving towards the state (from having no state partner to having a state partner) should have 
Table 2 State proximity dynamics and goal mix change

\begin{tabular}{|c|c|c|c|c|c|c|c|}
\hline & & & \multicolumn{4}{|c|}{ Goal-mix change } & \multirow[t]{2}{*}{ Total } \\
\hline & & & $\begin{array}{l}1 \text { stays } \\
\text { single issue }\end{array}$ & $\begin{array}{l}2 \text { more } \\
\operatorname{mix}\end{array}$ & $\begin{array}{l}3 \text { less } \\
\text { mix }\end{array}$ & $\begin{array}{l}4 \text { stays } \\
\text { mixed }\end{array}$ & \\
\hline \multirow{12}{*}{$\begin{array}{l}\text { State proximity } \\
\text { dynamics }\end{array}$} & \multirow{3}{*}{$\begin{array}{l}1 \text { state- } \\
>\text { state }\end{array}$} & Count & 26 & 24 & 26 & 59 & 135 \\
\hline & & Row \% & 19.3 & 17.8 & 19.3 & 43.7 & 100.0 \\
\hline & & Adj. Res. & -2.0 & -.6 & -.3 & 2.6 & \\
\hline & \multirow{3}{*}{$\begin{array}{l}2 \text { state- } \\
>\text { no state }\end{array}$} & Count & 12 & 14 & 16 & 19 & 61 \\
\hline & & Row \% & 19.7 & 23.0 & 26.2 & 31.1 & 100.0 \\
\hline & & Adj. Res. & -1.1 & .8 & 1.3 & -.8 & \\
\hline & \multirow{3}{*}{$\begin{array}{c}3 \text { no state- } \\
>\text { state }\end{array}$} & Count & 16 & 15 & 5 & 16 & 52 \\
\hline & & Row \% & 30.8 & 28.8 & 9.6 & 30.8 & 100.0 \\
\hline & & Adj. Res. & 1.0 & 1.9 & -2.1 & -.8 & \\
\hline & \multirow{3}{*}{$\begin{array}{l}4 \text { no state- } \\
>\text { no state }\end{array}$} & Count & 33 & 14 & 23 & 29 & 99 \\
\hline & & Row \% & 33.3 & 14.1 & 23.2 & 29.3 & 100.0 \\
\hline & & Adj. Res. & 2.2 & -1.5 & .9 & -1.5 & \\
\hline \multirow[t]{2}{*}{ Total } & & Count & 87 & 67 & 70 & 123 & 347 \\
\hline & & Row \% & 25.1 & 19.3 & 20.2 & 35.4 & 100.0 \\
\hline
\end{tabular}

$\chi^{2}=19.09, p=.024$

decreased goal diversity (the goal mix should become less mixed). This does not happen. Moves in the direction of the state go hand-in-hand with a declining probability of reduced goal diversity.

Another expectation is that those NGOs that stay away from the state should be over-represented among those NGOs that maintain a diverse goal mix. This hypothesis is also not supported: the no state-no state sequence is negatively associated with maintaining a mixed goal portfolio (although the statistical association is not significant: the adjusted standardized Pearson residual is -1.5 ).

The patterns of this table suggest that different processes are at work. Those NGOs that are repeatedly proximate to the state (the state-state sequence) are the most likely to maintain a mixed goal portfolio (with an adjusted standardized residual of 2.6 this is a statistically significant association). Those NGOs that never partner with the state (no state-no state sequence) are statistically more likely to stay single-issue. Approaching the state ("no state-state") is associated with a growing (diversifying) mix of goals (adjusted residual of 1.9). While in the state leaving group ("state-no state") the most overrepresented category is a simplifying goal mix. Changing state proximity is related to changing goal portfolio-but completely in the opposite direction that we expected.

We also tested other aspects of autonomy. The first, still concerning goals, is whether becoming connected to the state means that an NGO drops goals that it had before. This measure is different from the previous measure: goal diversity is more robust than any individual goals. An NGO can stay diversified in its goals yet loose one or more goals that it had before. We now test this more stringent criterion of losing autonomy (Table 3). 
Table 3 State proximity dynamics and goal loss

\begin{tabular}{|c|c|c|c|c|c|}
\hline & & & \multicolumn{2}{|c|}{ Lost a goal } & \multirow[t]{2}{*}{ Total } \\
\hline & & & No & Yes & \\
\hline \multirow{12}{*}{$\begin{array}{l}\text { State proximity } \\
\text { dynamics }\end{array}$} & \multirow[t]{3}{*}{1 state- $>$ state } & Count & 102 & 33 & 135 \\
\hline & & Row $\%$ & 75.6 & 24.4 & 100.0 \\
\hline & & Adj. Res. & .9 & -.9 & \\
\hline & \multirow[t]{3}{*}{2 state- $>$ no state } & Count & 44 & 17 & 61 \\
\hline & & Row \% & 72.1 & 27.9 & 100.0 \\
\hline & & Adj. Res. & -.2 & .2 & \\
\hline & \multirow[t]{3}{*}{3 no state- $>$ state } & Count & 41 & 11 & 52 \\
\hline & & Row \% & 78.8 & 21.2 & 100.0 \\
\hline & & Adj. Res. & 1.0 & -1.0 & \\
\hline & \multirow[t]{3}{*}{4 no state- $>$ no state } & Count & 66 & 33 & 99 \\
\hline & & Row \% & 66.7 & 33.3 & 100.0 \\
\hline & & Adj. Res. & -1.7 & 1.7 & \\
\hline \multirow[t]{2}{*}{ Total } & & Count & 253 & 94 & 347 \\
\hline & & Row \% & 72.9 & 27.1 & 100.0 \\
\hline
\end{tabular}

Overall there is no significant relationship between state proximity dynamics and losing goals. The direction of the-weak-statistical association is opposite to what we expected. An NGO that become proximate to the state ("no state-state") is slightly less likely than average to lose a goal. In the whole sample $27.1 \%$ of organizations lost a goal between their last two projects. Among those that become proximate to the state only $21.2 \%$ lost a goal. Among NGOs with stable state proximity ("statestate") $24.4 \%$ lost a goal. NGOs that ceased to exhibit state proximity ("state-no state") were the most likely category to experience goal loss: exactly one-third, $33.3 \%$ of these NGOs lost a goal.

\section{State Proximity and Political Activism}

After analyzing goals, the next step is to understand actions. When discussing autonomy, the most important kind of action is political activism, involving some kind of contention. This is a critical capacity of civil society, and contention is seen as involving the greatest risk when NGOs establish contacts with the state. Here again we focus on dynamics, changes in state proximity, and changes in political activism.

Table 4 presents the results about political activism and state proximity. Overall the statistical association is not significant. If we focus on standardized adjusted residuals, the highest deviation from expected frequencies is that those NGOs that exit state proximity ("state-no state") also become more passive (active-passive sequence). This is contrary to the expectation that state proximity will decrease activism. On the other hand, when an NGO becomes proximate to the state ("no 
Table 4 State proximity dynamics and political activism change

\begin{tabular}{|c|c|c|c|c|c|c|c|}
\hline & & & \multicolumn{4}{|c|}{ Political activism dynamics } & \multirow[t]{2}{*}{ Total } \\
\hline & & & $\begin{array}{l}1 \text { active- } \\
>\text { active }\end{array}$ & $\begin{array}{l}2 \text { active- } \\
>\text { passive }\end{array}$ & $\begin{array}{l}3 \text { passive- } \\
>\text { active }\end{array}$ & $\begin{array}{l}4 \text { passive- } \\
>\text { passive }\end{array}$ & \\
\hline \multirow{12}{*}{$\begin{array}{l}\text { State proximity } \\
\text { dynamics }\end{array}$} & \multirow{3}{*}{$\begin{array}{l}1 \text { state- } \\
\quad>\text { state }\end{array}$} & Count & 10 & 10 & 15 & 106 & 141 \\
\hline & & Row \% & 7.1 & 7.1 & 10.6 & 75.2 & 100.0 \\
\hline & & Adj. Res. & .9 & -.4 & .5 & -.6 & \\
\hline & \multirow{3}{*}{$\begin{array}{l}2 \text { state- } \\
\quad>\text { no state }\end{array}$} & Count & 3 & 10 & 3 & 49 & 65 \\
\hline & & Row \% & 4.6 & 15.4 & 4.6 & 75.4 & 100.0 \\
\hline & & Adj. Res. & -.4 & 2.5 & -1.5 & -.3 & \\
\hline & \multirow{3}{*}{$\begin{array}{c}3 \text { no state- } \\
>\text { state }\end{array}$} & Count & 3 & 4 & 9 & 46 & 62 \\
\hline & & Row \% & 4.8 & 6.5 & 14.5 & 74.2 & 100.0 \\
\hline & & Adj. Res. & -.3 & -.4 & 1.4 & -.5 & \\
\hline & \multirow{3}{*}{$\begin{array}{l}4 \text { no state- } \\
>\text { no state }\end{array}$} & Count & 6 & 6 & 10 & 93 & 115 \\
\hline & & Row \% & 5.2 & 5.2 & 8.7 & 80.9 & 100.0 \\
\hline & & Adj. Res. & -.3 & -1.2 & -.4 & 1.2 & \\
\hline \multirow[t]{2}{*}{ Total } & & Count & 22 & 30 & 37 & 294 & 383 \\
\hline & & Row \% & 5.7 & 7.8 & 9.7 & 76.8 & 100.0 \\
\hline
\end{tabular}

$\chi^{2}=10.57, p=.307$

state-state") then the sequence of political activation ("passive-active") is overrepresented. Contact with the state goes together with increasing political activism.

We have also used logistic regression models to tests the above hypotheses including controlling variables (results not shown here). They also failed to provide support for the hypothesis about the negative relationship between state proximity and autonomy. The models we used were not significant overall. In the model we tested loss of goals as the dependent variable, the only significant coefficient we found was that approximating the state makes it significantly less likely that an organization will drop goals. In the model where political activism was the dependent variable, we found that organizations that leave the state are more likely to stop being politically active.

\section{Loss of Autonomy: Alternative Explanations}

We found that the dynamics of state proximity are not associated with changes in political activism in the hypothesized way. We subjected this negative finding to further scrutiny by assessing three alternative hypotheses. The lack of expected statistical association between state proximity, goal loss, and political activism can be attributed to competing forces that deactivate NGOs in the civic and political fields.

One alternative expectation is that the commodification of civil society projects leads to de-politicization. According to this expectation, as NGOs engage in partnerships with business organizations, they adopt the market regime of worth, 
and think about their activities as marketable services. This framing might be incompatible with their previous goals, and especially political activism, so we expect NGOs to lose their political activism as they start collaborating with business organizations.

A second alternative expectation concerns the effects of losing civic control. NGOs often collaborate with other NGOs in their projects. These collaborations can be thought of as vehicles of collective monitoring, where it becomes possible to sanction divergence from civic values. Once NGOs leave such collaborative projects with other NGOs and engage in projects alone, they might loose civic control, and hence might be more likely to abandon previous goals, and less likely to engage in political activism.

A third alternative explanation for the loss of political activism concerns reduced public attention-cutting collaborative ties to media organizations. Reputation is an important currency in the NGO world. NGOs that collaborate with media organizations are probably more careful not to abandon civic goals. We expect that NGOs that move to projects without the participation of media organizations after previous projects with media partnerships will be more likely to abandon their original goals, and their political activism.

To test these alternative expectations we constructed contingency tables following the same logic that we used in testing the hypothesis about the dynamics of state proximity and change in political activism and the change in goals. Based on

the $\chi^{2}$-tests and Pearson standardized residuals we can reject all three alternative hypotheses.

As NGOs pick up project partnerships with businesses they become significantly more likely to pick up new goals, and thus follow more diverse goals. This is contrary to our expectations. NGOs do not drop their goals when they partner with business, they do however lose goals when they exit such partnerships. Partnering with business does not seem to hurt civic values and goals. We found no statistical association between business partnership and political activism.

NGOs do not drop goals or become de-politicized when they leave projects with other NGOs and engage in solo projects. It seems that civic control is maintained through different channels, not primarily through co-organized projects.

The presence of media partners in NGO projects does not seem to be associated with goal loss or political deactivation. Again, we need to rethink the nature of the public in which civic projects are embedded. The absence of direct media attention does not result in NGO opportunism.

\section{Factors of Political Action}

We found no support for hypotheses about autonomy loss connected to state proximity. A declining number of goals, diminishing mix of goals, and waning political activism go together with a distancing from the state. But do our indicators really measure autonomy? Might it not, for example, be possible that, just to the contrary, the presence of, or increase in political activism indicates a loss or lack of autonomy? 
We stated that the most important kind of action in the context of autonomy is political activism involving some kind of contention. This is a critical capacity of civil society, and contention is seen at the highest risk when NGOs establish contacts with the state. In previous analyses we assumed that political action is an automatic sign of civic autonomy. Here we relax this assumption and consider alternative explanations for political action. It might be that political activism is not about autonomy but, just to the contrary, is a sign of the lost or nonexistent autonomy of these organizations.

One possibility that we have considered was that political action was primarily about money: political action might have not much to do with the desire to represent local interests or increase room for decentralized experimentation. Instead, by engaging in political action COs "go for money." COs that have applied successfully for central government or local government funds might have strong incentives to try again, and are accordingly more likely to enter in political actione.g., into lobbying the (local, regional, or national) state to frame developmental programs in the "right way." To control for the effect of this factor, we used two variables: whether the $\mathrm{CO}$ applied successfully for central government money ("Money from government") and whether the CO applied successfully for local state money ("Money from local government").

A second possibility that we have considered was that it is not the autonomous COs that engage in political action but rather the NGOs created by the local state. Such "subsidiary NGOs" might be the convenient lobbying arms of the local governments giving a "civic" voice to local alliances trying to influence the central state. To control for this effect we have used questions about the founders of the NGOs and the membership of (local) state actors in the leading bodies of the NGOs. If the (local) state was among the founders of the organizations and/or it was represented on the leading body of the organization we counted the organization as a "subsidiary NGO" ("Founded by local government").

We have tested several alternative explanations for political activism drawing freely on organizational theories and theories developed on the basis of the study of the political organization of business.

One alternative might be that political activism is the effect of local accountability relations: COs deeply embedded in the local society will not lose their autonomy while combining with the state and are actually pushed into politics. The extensive networks of accountability to local actors (members, clients, other COs, the local public, etc.), whilst preventing regional COs from losing their autonomy, also push them to pursue their goals both by participating in partnerships and by politicizing the goals and values they represent. This hypothesis draws on and extends the "logic of membership" argument of Schmitter and Streeck (1999): organizational behavior is the function of local roots (characteristics of the accountability to members).

Informal and formal accountability to local social actors means that COs have to take into account the interests of diverse local actors when making decisions and/or have to report to them. To assess the role of informal and formal accountability we used the following variables in the equations below: 
1/ the $\mathrm{CO}$ has to take into account the interests of members, clients, other domestic NGOs, foreign NGOs, the media/newspapers, the general public and the trade unions

2/ the CO has to formally report to members, clients, other domestic NGOs, foreign NGOs, the media/newspapers, the general public and the trade unions

We take our second alternative explanation from another co-authored paper of Streeck and Schmitter: a specific pattern of state-NGO relationship pulls NGOs into policy networks and makes them combine participation in collaborative projects with political action (Streeck and Schmitter 1985). State actors, according to Streeck and Schmitter, might have little incentive to work with non-autonomous COs; rather, they might need contextualized information and guarantees for both responsive policies and smooth implementation. Joint projects with COs are normal political exchanges: state actors have strong incentives to find autonomous partners and local COs need opportunities to pursue their goals. The stronger and more encompassing the collaboration between state actors and COs, the higher the likelihood that COs become part of policy networks. It is not closeness to the state per se, but a specific pattern of interactions between the state and COs that accounts for political activism. Or, put simply, political action by COs is the effect of deep integration with the state. We test this hypothesis by using the results of a cluster analysis of the different types of interactions between the central state and the local COs (results not shown here). In the equations below we use the cluster of "Deep integration' with government." This is a pattern of interaction with government that combines direct participation of a state actor in the projects of the $\mathrm{CO}$ with formal and informal accountability relationships and monetary contributions to the project.

A third explanation might be the size of the $\mathrm{CO}$ : larger, more resourceful COs, and COs that are not dependent on a small number of sources for money might be more able to afford to engage in political action. In the equations below we used the logarithm of the size of the budget of the $\mathrm{CO}$ and the diversity of the sources of $\mathrm{CO}$ revenue (types of monetary sources) to control for this effect.

A fourth explanation might be that goal combination might push COs into political action: COs learn by combining. By pursuing more diverse goals they are more likely to meet more diverse partners and are more likely to discover new combinations of developmental goals and face the limitations in the way developmental programs are framed by the state. This "learning through combining" might push COs to alter definitions of developmental goals and/or to frame programs and policies in a more inclusive fashion. To test this hypothesis we have used "goal mix," standing for COs that combine all the three types of goals (economic, social, and territorial-environmental) in their projects that we have used in questionnaire. Finally, COs in one region might have different opportunities to enter into political action than in others. We include variables for the Southern Plain and Western Hungary, omitting the Northern Plain as the reference category.

Since political activism and partnerships happen at the level of projects and ongoing activities, in this part of the analysis we use projects and activities as units of analysis. The number of cases ranges between 1,243 and 1,279 in the three models. 


\section{Political Action: Attempt to Change Regulations}

In the first equation below we used a logistic regression analysis with attempt to change regulation at the level of central or local government as our dependent variable (Table 5).

This model does not support the hypothesis that political activity is about funding. The fact that a $\mathrm{CO}$ has applied successfully for central government money or for local state money does not predict attempts to change regulations. We must also reject the hypothesis that subsidiary NGOs are more likely to enter in political action.

Table 5 Logistic regression, dependent variable: Attempt to change regulation at the level of central or local government

\begin{tabular}{|c|c|c|c|c|c|}
\hline & $B$ & $\operatorname{Exp}(B)$ & SE & Wald & Sig. \\
\hline Goal mix & $.599 * *$ & 1.820 & .152 & 15.557 & .000 \\
\hline \multicolumn{6}{|l|}{ Taking into account } \\
\hline Members & $.407 *$ & 1.502 & .206 & 3.919 & .048 \\
\hline Clients & -.091 & .913 & .182 & .251 & .616 \\
\hline Domestic NGOs & .161 & 1.175 & .183 & .773 & .379 \\
\hline Foreign NGOs & $.453^{*}$ & 1.574 & .205 & 4.872 & .027 \\
\hline Media organizations & .189 & 1.208 & .183 & 1.068 & .301 \\
\hline General public & .350 & 1.419 & .199 & 3.079 & .079 \\
\hline Trade unions & .383 & 1.467 & .316 & 1.472 & .225 \\
\hline \multicolumn{6}{|l|}{ Reporting to } \\
\hline Members & $.397 *$ & 1.488 & .168 & 5.619 & .018 \\
\hline Clients & .232 & 1.261 & .203 & 1.298 & .254 \\
\hline Domestic NGOs & .013 & 1.013 & .191 & .005 & .946 \\
\hline Foreign NGOs & .038 & 1.038 & .267 & .020 & .888 \\
\hline Media organizations & -.154 & .858 & .215 & .509 & .476 \\
\hline General public & .267 & 1.306 & .200 & 1.790 & .181 \\
\hline Trade unions & -.369 & .691 & .402 & .845 & .358 \\
\hline Logarithm of budget & $.590 * *$ & 1.804 & .102 & 33.125 & .000 \\
\hline Types of monetary sources & -.040 & .961 & .039 & 1.018 & .313 \\
\hline Money from government & .108 & 1.114 & .157 & .478 & .489 \\
\hline Money from local government & .056 & 1.058 & .166 & .114 & .736 \\
\hline Founded by local government & .175 & 1.191 & .171 & 1.047 & .306 \\
\hline Dependent on local government & .043 & 1.044 & .176 & .059 & .807 \\
\hline Deep integration with government & $.781 * *$ & 2.184 & .218 & 12.828 & .000 \\
\hline Southern Plain & -.167 & .846 & .163 & 1.047 & .306 \\
\hline Western Hungary & $-.482 * *$ & .618 & .162 & 8.898 & .003 \\
\hline Constant & $-3.006^{* *}$ & .049 & .466 & 41.638 & .000 \\
\hline
\end{tabular}

$N=1,243$, Nagelkerke $R^{2}: .253$

$* p<0.05$; ** $p<0.01$ 
Goal combination has a significant effect on political action: highly combinatory COs are 1.8 times more likely to change central or local government regulations. Accountability to local actors is another significant and independent predictor of political action: COs that must take into account the interests of their members are 1.5 times more likely to enter in this type of political action. The effect of formal reporting requirements to members is similar. Whether or not COs take into account the interests of foreign NGOs and of the general public has the same effect.

The effect of the size of budget is also significant. COs with a budget one order of magnitude greater (we used base-ten logarithm here) are 1.8 times more likely to engage in this type of political action. COs that are deeply integrated in their interactions with the central government are 2 times more likely to enter in political action. Finally, COs in Western Hungary are significantly less likely to engage in political action.

\section{Political Action: Trying to Change the Balance of Forces}

In the second equation below we used as our dependent variable whether or not COs had attempted to change the balance of forces in the CO's area of activity.

As in the equation above, local social relations of accountability matter significantly. COs that have to take into account the interests of their members are 1.8 times more likely to alter the balance of forces. The effects of the need to take into account the interests of general public, the interests of trade unions, and formal reporting requirements to the general public are similar. Goal combination, on the other hand, is not a predictor of this type of political action. COs which complain of excessive dependency on local governments are 1.8 times more likely to enter into this type of political action.

This model also fails to support the hypothesis that political action is about money. The fact that a CO has applied successfully for central government money or for local state money does not predict attempts to undertake this type of political action. We must also reject the hypothesis that subsidiary NGOs are likely to enter into this type of political action. Resources matter significantly: COs with larger budget are 1.2 times more likely to try to alter the balance of forces. As above, COs from Western Hungary are less likely to act (Table 6).

\section{Political Action: Lobbying Central Government}

Finally, in the third equation below we used lobbying central government as the dependent variable (Table 7).

It is in this equation that we find an independent effect of receiving money from central and local government. Both matter but in dramatically different ways. Successful applications for central government money significantly increases, successful application for local state money significantly decreases, the probability of lobbying central government. This, however, is not the full picture. High goal 
Table 6 Logistic regression, dependent variable: Attempts to alter the balance of forces

\begin{tabular}{|c|c|c|c|c|c|}
\hline & $B$ & $\operatorname{Exp}(B)$ & SE & Wald & Sig. \\
\hline Goal mix & .216 & 1.242 & .144 & 2.246 & .134 \\
\hline \multicolumn{6}{|l|}{ Taking into account } \\
\hline Members & $.597 * *$ & 1.817 & .198 & 9.066 & .003 \\
\hline Clients & .025 & 1.025 & .177 & .020 & .889 \\
\hline Domestic NGOs & .203 & 1.225 & .181 & 1.258 & .262 \\
\hline Foreign NGOs & .203 & 1.225 & .199 & 1.044 & .307 \\
\hline Media organizations & -.328 & .720 & .181 & 3.294 & .070 \\
\hline General public & $.539 * *$ & 1.715 & .195 & 7.626 & .006 \\
\hline Trade unions & $.669^{*}$ & 1.952 & .294 & 5.181 & .023 \\
\hline \multicolumn{6}{|l|}{ Reporting to } \\
\hline Members & .088 & 1.092 & .162 & .293 & .588 \\
\hline Clients & .093 & 1.098 & .190 & .241 & .624 \\
\hline Domestic NGOs & -.087 & .917 & .183 & .226 & .635 \\
\hline Foreign NGOs & .179 & 1.196 & .252 & .504 & .478 \\
\hline Media organizations & -.099 & .906 & .207 & .228 & .633 \\
\hline General public & $.553^{* *}$ & 1.739 & .192 & 8.289 & .004 \\
\hline Trade unions & .548 & 1.730 & .428 & 1.639 & .200 \\
\hline Logarithm of budget & $.194 *$ & 1.214 & .098 & 3.878 & .049 \\
\hline Types of monetary sources & -.009 & .991 & .038 & .056 & .812 \\
\hline Money from government & .249 & 1.283 & .155 & 2.578 & .108 \\
\hline Money from local government & .200 & 1.221 & .161 & 1.544 & .214 \\
\hline Founded by local government & -.229 & .796 & .166 & 1.897 & .168 \\
\hline Dependent on local government & $.632 * *$ & 1.882 & .179 & 12.536 & .000 \\
\hline Deep integration with government & .126 & 1.134 & .198 & .405 & .525 \\
\hline Southern Plain & .143 & 1.154 & .159 & .805 & .369 \\
\hline Western Hungary & $-.327^{*}$ & .721 & .155 & 4.430 & .035 \\
\hline Constant & $-1.850^{* *}$ & .157 & .446 & 17.207 & .000 \\
\hline
\end{tabular}

$N=1,266$, Nagelkerke $R^{2}: .212$

$* p<0.05 ; * * p<0.01$

combination doubles the probability of lobbying the government. Also, as in the equations above, relations of local accountability are independent predictors of political action: the need to take into account the interests of members, the need to take into account the interests of trade unions and the requirement to report to other domestic NGOs all significantly increase the probability of lobbying central government.

Resources also matter: more resourceful COs, or COs that have more diverse resource portfolios are somewhat more likely to lobby central government. Finally, deep collaboration of COs with central government nearly doubles the probability of this type of political action. 
Table 7 Logistic regression, dependent variable: Lobbying central government

\begin{tabular}{|c|c|c|c|c|c|}
\hline & $B$ & $\operatorname{Exp}(B)$ & SE & Wald & Sig. \\
\hline Goal mix & $.718 * *$ & 2.050 & .143 & 25.274 & .000 \\
\hline \multicolumn{6}{|l|}{ Taking into account } \\
\hline Members & $.451 *$ & 1.570 & .231 & 3.829 & .050 \\
\hline Clients & -.211 & .810 & .200 & 1.107 & .293 \\
\hline Domestic NGOs & -.031 & .970 & .195 & .025 & .874 \\
\hline Foreign NGOs & -.105 & .900 & .199 & .281 & .596 \\
\hline Media organizations & -.174 & .840 & .186 & .874 & .350 \\
\hline General public & .173 & 1.188 & .213 & .658 & .417 \\
\hline Trade unions & $.592 *$ & 1.808 & .260 & 5.205 & .023 \\
\hline \multicolumn{6}{|l|}{ Reporting to } \\
\hline Members & .063 & 1.065 & .178 & .125 & .724 \\
\hline Clients & -.012 & .988 & .196 & .004 & .953 \\
\hline Domestic NGOs & $.374 *$ & 1.453 & .188 & 3.950 & .047 \\
\hline Foreign NGOs & .201 & 1.223 & .234 & .740 & .390 \\
\hline Media organizations & -.048 & .953 & .200 & .059 & .808 \\
\hline General public & -.012 & .988 & .201 & .004 & .951 \\
\hline Trade unions & .090 & 1.095 & .341 & .070 & .791 \\
\hline Logarithm of budget & $.245^{*}$ & 1.277 & .105 & 5.468 & .019 \\
\hline Types of monetary sources & .089 & 1.093 & .040 & 4.974 & .026 \\
\hline Money from government & $.574 * *$ & 1.775 & .170 & 11.457 & .001 \\
\hline Money from local government & $-.530 * *$ & .589 & .174 & 9.311 & .002 \\
\hline Founded by local government & -.251 & .778 & .177 & 2.012 & .156 \\
\hline Dependent on local government & -.346 & .708 & .186 & 3.436 & .064 \\
\hline Deep integration with government & $.679 * *$ & 1.973 & .185 & 13.528 & .000 \\
\hline Southern plain & -.098 & .907 & .162 & .368 & .544 \\
\hline Western Hungary & $-.468 * *$ & .626 & .167 & 7.869 & .005 \\
\hline Constant & $-2.954 * *$ & .052 & .488 & 36.626 & .000 \\
\hline
\end{tabular}

$N=1,279$, Nagelkerke $R^{2}: .164$

$* p<0.05 ; * * p<0.01$

\section{Conclusions}

In this article we have explored the ways in which partnerships with the state within state-led developmental programs might effect the autonomy of civic organizations and their readiness to enter in political action. We did not find support for the theses that mixing with the state might undermine the autonomy of COs, and lead to their political neutralization. Nor did we find support for the hypotheses that political action is solely about money or it is the exclusive preserve of subsidiary NGOs. We have identified several mechanisms that allow COs to combine participation in partnership projects whilst maintaining political activism.

Based on the work of Schmitter and Streeck, we expected that the "logic of local embedding" will be one of the factors of pushing COs towards political action. We 
found that participatory COs that are accountable to their members, and that are integrated in local societies are significantly more likely to engage in political action, either by trying to change regulations, by lobbying, or by trying to change the balance of forces in their field of action. We also tested the "learning by combining" hypothesis. We found that intense combinations with actors from other organizational fields, including the state, far from reducing political activism, is instead an independent factor in explaining civic political activity. Finally, we tested the "political exchange" hypothesis and found that deeper forms of collaboration with the state significantly increase the likelihood of civic political action. Using the language of the social movement studies, we can say that the changed opportunity structure (the growing possibility of combining with the state in developmental projects) alters CO's action repertoire but does not transform activist organizations into mere service organizations. ${ }^{8}$ The growth in collaborative developmental projects does not endanger the autonomy of integrated civil societies.

Based on our findings we can also say that it is misleading to underestimate the transformative potential of associative civic action involving collaboration with actors from other organizational fields. ${ }^{9}$ In forging various developmental associations, civic organizations that work together with actors from other organizational domains (business, national and local government, education, church, etc.) can contribute to the coming about of local and regional publics, thereby allowing the formulation and implementation of more inclusive policies and programs. While making alliances across groupings and integrating what had formerly been disjointed, civic organizations' projects draw connections between interests that perhaps had not been seen as compatible. They are therefore producing new frames in which dissimilar notions of the public good can be redefined and associated. In that sense, the combination of associating diversity in ever-changing developmental projects with political action might lead to the occurrence of what Fraser called "strong publics:" arenas for assembling diverse ideas, metrics of valuation, and interests for joint policy formulation, not just implementation (Fraser 1994).

\section{References}

Anderson, K. (2000). The ottawa convention banning landmines, the role of international nongovernmental organizations and the idea of international civil society. European Journal of International Law, 11(1), 91-120.

Brown, L., Khagram, S., Moore, M, \& Frumkin, P. (2001). Globalization, NGOs, and multi-sectoral relations. In J. S. Nye Jr. \& J. D. Donohue (Eds.), Governance in a globalizing world (pp. 271-296). Washington, DC: Brookings Institution.

Bruszt, L. (2002). Making markets and Eastern enlargement: Diverging convergence? In P. Mair \& J. Zielonka (Eds.), The enlarged European Union: Diversity and adaptation (pp. 121-141). London, Portland: Frank Cass.

Bruszt, L., \& Stark, D. (2003). Who counts? Supranational norms and societal needs. East European Politics and Societies, 17, 74-82.

\footnotetext{
${ }^{8}$ See Tarrow (1998) for the discussion of opportunity structures, and form and types of organizing.

9 See our article co-authored with David Stark for further discussion of civic associative action (Stark et al., Unpublished manuscript, 2005).
} 
Chandhoke, N. (2002). The limits of global civil society. In M. Glasius, M. Kaldor, \& H. K. Anheier (Eds.). Global civil society yearbook 2002 (pp. 35-53). Oxford: Oxford University Press.

Evans, P. (1997). State-society synergy: Government and social capital in development. International and Area Studies, University of California at Berkeley.

Fraser, N. (1994). Rethinking the public sphere: A contribution to the critique of actually existing democracy. In C. Calhoun (Ed.), Habermas and the public sphere (pp. 109-142). Cambridge, MA: MIT Press.

Gerstenberg, O., \& Sabel, C. F. (2002). Directly deliberative polyarchy: An institutional ideal for Europe? In C. Joerges \& R. Dehousse (Eds.), Good governance in Europe's integrated market (pp. 289-341). Oxford: Oxford University Press.

Howell, J., \& Pearce, J. (2002). Civil society and development: A critical exploration. Boulder, CO: Lynne Rienner.

Kaldor, M., Anheier, H. K., \& Glasius, M. (2003). Global civil society yearbook 2003. Oxford: Oxford University Press.

Kettle, D. (2000). The global public management revolution: A report on the transformation of governance. Washington, DC: Brookings Institution.

OECD (1995). Participatory development and good governance. Paris: Development Cooperation Guidelines Series, Organization for Economic Cooperation and Development.

Perrow, C. (2001). The rise of nonprofits and the decline of civil society. In H. Anheier (Ed.), Organizational theory and nonprofit form. (Report no. 2) (pp. 33-44). Centre for Civil Society, London School of Economics.

Perrow, C. (2002). Organizing America: Wealth, power and the origins of American capitalism. Princeton, NJ: Princeton University Press.

Powell, W., \& Clemens, E. (1998). Private action and the public good. New Haven, London: Yale University Press.

Sabel, C. (1993). Studied trust: Building new forms of cooperation in a volatile economy. Human Relations, 46(9), 214-267.

Sabel, C. (1994). Learning by monitoring: The institutions of economic development. In N. Smelser \& R. Swedberg (Eds.), Handbook of Economic Sociology (pp. 137-165). Princeton, NJ.: Princeton University Press and Russell Sage Foundation.

Sabel, C. (1996). Ireland: Local partnerships and social innovation. OECD Publications.

Sabel, C., \& Cohen, J. (1997). Directly-deliberative polyarchy. European Law Journal, 3(4), 313-342.

Schmitter, P. C., \& Streeck, W. (1999). The organization of business interests: Studying the associative action of business in advanced industrial societies. Max Planck Institute fur Gesellschaftsforschung, Discussion Papers 99/1.

Stark, D., \& Bruszt, L. (1998). Postsocialist pathways: Transforming politics and property in East Central Europe. New York, Cambridge: Cambridge University Press.

Streeck, W., \& Schmitter, P. C. (1985). Community, market, state-and associations? The prospective contribution of interest governance to social order. In W. Streeck \& P. C. Schmitter (Eds.), Private interest government. Beyond market and state (pp. 1-34). Sage: London.

Tarrow, S. (1998). Power in movement: Social movements and contentious politics. Cambridge: Cambridge University Press.

UNDP (1993). UNDP and organizations of civil society: Building sustainable partnerships. November, Mimeo.

UNDP (1995). Proposed UNDP Regional Programme: Civil society empowerment for poverty reduction in sub-Saharan Africa. January, Mimeo.

World Bank (1992). Governance and development. Washington, DC: World Bank.

World Bank (1996). The World Bank's partnership with nongovernmental organizations. Washington, DC.: World Bank. 